\title{
JARAK GENETIK SAPI PASUNDAN MELALUI PENDEKATAN KRANIOMETRI ANTAR WILAYAH PANGANDARAN, TASIKMALAYA DAN GARUT JAWA BARAT
}

\author{
Johar Arifin ${ }^{1^{*}}$, Sulasmi ${ }^{2}$ \\ ${ }^{1)}$ Fakultas Peternakan Universitas Padjajaran, Sumedang, \\ 2) Program Studi Peternakan Fakultas Pertanian Universitas Khairun, Ternate \\ "E-mail: johararifin74@gmail.com.
}

\begin{abstract}
Sumber daya genetik sapi Pasundan di wilayah pesisir selatan Jawa Barat mengalami penurunan populasi. Salah satu dampak dari penurunan populasi ternak adalah degradasi kualitas dan kemurnian ternak. Penelitian tentang jarak genetik populasi sapi pasundan antar wilayah Pangandaran, Tasikmalaya dan Garut, Jawa Barat bertujuan mengetahui deskripsi dan hubungan kekerabatan populasi sapi Pasundan di wilayah pesisir selatan Jawa Barat dengan menggunakan pendekatan kraniometri. Penelitian dilaksanakan pada September sampai Desember 2018. Analisis data menggunakan analisis deskripstif dan analisis kluster melalui software SPSS 16. Hasil penelitian menunjukkan ukuran-ukuran kranium antar populasi tidak memiliki perbedaan yang nyata $(P>0.05)$. Jarak genetik antar populasi pada wilayah Pangandaran, Tasikmalaya dan Garut Jawa Barat berdasarkan jarak Euclidean menggunakan Cluster Analysis menunjukkan hubungan kekerabatan antar populasi yang masih tinggi. Penurunan populasi antar wilayah basis populasi sapi pasundan di wilayah pesisir selatan Jawa Barat belum menunjukkan adanya degradasi genetik. Namun perlu adanya antisipasi dalam meningkatkan ukuran populasi efektif melalui aplikasi teknologi bioreproduksi seperti super ovulasi dan inseminasi buatan menggunakan sperma pejantan sapi pasundan yang telah diproduksi oleh Pemerintah Provinsi Jawa Barat.
\end{abstract}

Kata Kunci: sapi pasundan, jarak genetik, pendekatan kraniometri, aplikasi teknologi bioreproduksi.

\section{PENDAHULUAN}

Sapi Pasundan merupakan sumber daya genetik khas Jawa Barat, sesuai dengan SK Menteri Pertanian Nomor 1051/Kpts/RI/SR.120/10/2014 tentang penetapan rumpun sapi Pasundan sebagai SDGT Jawa Barat. Penetapan rumpun sapi lokal Jawa Barat ini memiliki tujuan antara lain pelestarian dan pemafaatan plasma nutfah secara optimal oleh pemerintah dan masyarakat, menjamin keragaman plasma nutfah untuk mencegah setiap ancaman terhadap ketahanan pangan nasional dan melindungi keragaman genetiknya. Eksistensi sapi Pasundan berada di peternakan rakyat dengan orientasi produksi pedet. Wilayah basis populasi menyebar di sepanjang priangan bagian utara dan pesisir selatan Jawa Barat.

Populasi sapi Pasundan di wilayah pesisir selatan Jawa Barat menyebar dari kabupaten Pangandaran, Tasikmalaya, Garut, Cianjur dan Sukabumi. Populasi ternak di wilayah tersebut mengalami penurunan sebanyak 21,96 persen sejak tahun 2014 sampai 2017 berdasarkan Arifin, (2016) dan (2017). Penurunan populasi ini disebabkan oleh beberapa faktor, antara lain:

1. Peningkatan harga jual sapi potong secara masif sejak tahun 2014 menyebabkan peternak akan mudah melepaskan ternak keluar dari populasi;

2. Penurunan daya dukung wilayah penggembalaan. Sapi Pasundan dipelihara 
masyarakat dengan pola semi intensif dan ekstensif, hal ini membutuhkan ketergantungan sumberdaya lain seperti perkebunan dan kehutanan untuk lahan penggembalaan;

3. Penurunan jumlah pejantan di lokus populasi menyebabkan jumlah calf crop menurun drastis sebagai akibat layanan reproduksi yang masih tradisional;

4. Pola warisan ternak dari pemilik (peternak) ke anak-anaknya, namun para generasi berikutnya meninggalkan usaha ini dan menjual ternak hasil warisannya.

5. Pola warisan tanah dari pemilik ternak ke anak-anaknya menyebabkan kapasitas tampung untuk perkandangan menyempit sehingga ternak dijual dan keluar dari lokus populasi.

Penurunan jumlah populasi ternak dapat berakibat fatal bagi konservasi sumberdaya genetik ternak. Penurunan populasi dapat menurunkan nilai ukuran populasi efektif. Menurut Subandriyo (2006) bahwa nilai populasi efektif yang rendah dapat meningkatkan tekanan inbreeding dan menyebabkan kepunahan. Populasi yang rendah pada pejantan juga menyebabkan migrasi gen dari pejantan bangsa atau rumpun lain yang masuk ke dalam populasi sapi Pasundan. Dengan demikian dapat digambarkan bahwa penurunan populasi di suatu wilayah secara genetis dapat menyebabkan degradasi genetik dan penurunan kemurnian sumberdaya genetik ternak.

Berdasarkan ilustrasi di atas maka perlu dieksplorasi dan dikaji secara dinamis kondisi genetik dalam populasi di wilayah-wilayah yang mengalami penurunan populasi, antara lain wilayah Pangandaran, Tasikmalaya dan Garut. Instrumen untuk mengkaji kondisi genetik di wilayah-wilayah tersebut antara lain menganalisis jarak genetik antar populasi. Salah satu metode dalam mengukur jarak genetik adalah menggunakan pendekatan kraniometri. Metode ini dinilai lebih murah dan efisien (Mahdi et al., 2013). Jarak genetik digunakan untuk mendeskripsikan hubungan kekerabatan populasi antar wilayah.

Tujuan dari penelitian ini adalah mengetahui deskripsi ukuran-ukuran bagian kranium antar populasi di wilayah Pangandaran,
Tasikmalaya dan Garut Jawa Barat dan menganalisis hubungan kekerabatan antar populasi sapi Pasundan di wilayah pesisir selatan Jawa Barat. Hasil penelitian ini dapat memberikan kontribusi berupa rekomendasi akademik dalam program konservasi sumberdaya genetik ternak khususnya sapi Pasundan di Jawa Barat.

\section{METODE PENELITIAN}

Penelitian ini dilaksanakan sejak bulan September sampai Desember 2018. Metode penelitian yang digunakan adalah metode deskriptif. Pengambilan data dilakukan secara survei, penentuan sampel dimulai dari sampel lokasi, kelompok ternak dan lokus populasi ternak. Pemilihan sampel lokasi dan kelompok ternak dilakukan secara purposive, yakni wilayah dan lokus populasi yang menjadi basis populasi. Sedangkan pemilihan sapi Pasundan berdasarkan dengan kemurnian yang tinggi merujuk pada hasil penelitian Arifin (2017).

Tabel 1. Lokasi dan kelompok ternak sapi Pasundan dalam Penelitian

\begin{tabular}{|l|l|l|}
\hline Wilayah Terpilih & $\begin{array}{l}\text { Kelompok } \\
\text { Ternak }\end{array}$ & $\begin{array}{l}\text { Jumlah } \\
\text { Populasi }\end{array}$ \\
\hline $\begin{array}{l}\text { Desa Ciakar } \\
\text { Kecamatan } \\
\text { Cijulang } \\
\text { Kabupaten } \\
\text { Pangandaran }\end{array}$ & $\begin{array}{l}\text { Kelompok } \\
\text { Ternak } \\
\text { Taruna } \\
\text { Muda Tiga }\end{array}$ & 320 ekor \\
\hline $\begin{array}{l}\text { Desa Sirnajaya } \\
\text { Kecamatan } \\
\text { Sukaraja } \\
\text { Kabupaten } \\
\text { Tasikmalaya }\end{array}$ & $\begin{array}{l}\text { Kelompok } \\
\text { Ternak } \\
\text { Lembu }\end{array}$ & 240 ekor \\
\hline $\begin{array}{l}\text { Desa } \\
\text { Mancagahar } \\
\text { Kecamatan } \\
\text { Pameungpeuk } \\
\text { Kabupaten Garut }\end{array}$ & $\begin{array}{l}\text { Kelompok } \\
\text { Ternak } \\
\text { Pasirpogor }\end{array}$ & 653 ekor \\
\hline
\end{tabular}

Pemilihan sampel ternak adalah betina yang dipilih secara random sampling pada ternak yang memiliki kesamaan umur, yaitu dua 
sampai tiga tahun. Penentuan umur ternak dilakukan berdasarkan catatan ternak atau informasi dari peternak. Adapun presentase pengambilan sampel sebanyak $30 \%$ dari populasi tiap wilayah. Sampel ternak terpilih adalah ternak yang mempunyai kondisi sehat seperti mata bersinar cerah, bulu halus mengkilat serta bercahaya, kulit bersih, dan lincah.

Peralatan yang digunakan untuk mengukur kranium sapi adalah meteran kain, kaliper, alat tulis dan kamera digital. Pengukuran dilakukan ketika ternak berada pada kondisi berdiri normal.

Ukuran kraniometri diperoleh dari perhitungan ukuran-ukuran kepala, sebagaimana sketsa dan gambar berikut ini :

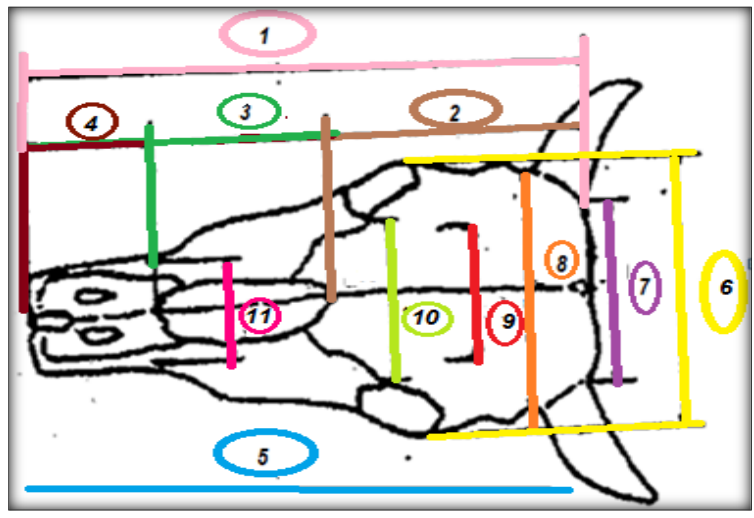

Gambar 1. Ukuran-ukuran kranium pada sapi Pasundan (Sulasmi, 2016) modifikasi Hayashi et al. (1982)

Keterangan :

1. Profile length, variabel dari pengukuran jarak Akrokranion (A) sampai Prosthion (P).

2. Median frontal length, variabel dari pengukuran jarak akrokranion (A) sampai Nasion (N).

3. Length of the nasals, variabel dari pengukuran jarak Nasion (N) sampai Rhinion (Rh).

4. Foramen gums length, variabel yang didapatkan dari pengukuran jarak Rhinion (Rh) sampai Prosthion (P).
5. Condilo basal length, variabel yang didapatkan dari pengukuran jarak Basion (B) sampai Prosthion (P).

6. Greatest breath of the skull, variabel dari pengukuran jarak Zygon (-Zy).

7. Least Breadth between the basses of the horn cores, variabel yang didapatkan dari pengukuran jarak antar Fossotemporale $(-\mathrm{Ft})$.

8. Least frontal breadth, variabel yang didapatkan dari pengukuran jarak antar Euryon (-Eu).

9. Least breadth between supraorbital foramina, variabel dari pengukuran jarak antar Supraorbitale (-Sp).

10. Least breadth between the orbits, variabel yang didapatkan dari pengukuran jarak antar Entorbitale (-Ent).

11. Breadth between supraorbital foramina, variabel dari pengukuran jarak antar Infraorbitale (If)

\section{Analisis Data}

Hasil pengukuran datasheet Excel ditabulasi dan dianalisis secara deskriptif. Untuk mengetahui perbedaan antar ukuran kranium menggunakan Anova. Sedangkan hubungan kekerabatan antara populasi di tiga wilayah menggunakan cluster analysis. Berdasarkan 11 indikator tersebut semuanya dapat membedakan sebuah klaster dengan klaster lainnya. Jarak Euclidean, menggunakan Cluster Analysis (Mahdi, 2013) dengan software SPSS 16.

\section{HASIL DAN PEMBAHASAN}

Populasi sapi Pasundan yang menyebar di wilayah pesisir selatan Jawa Barat berada di peternakan rakyat. Sapi Pasundan di wilayah Pangandaran terdapat di empat kecamatan, yakni kecamatan Pangandaran, Parigi, Cijulang dan Cimerak. Orientasi utama pemeliharaan ternak adalah produksi pedet. Modus pola pemeliharaan sapi Pasundan di wilayah Pangandaran adalah ekstensif dan semi intensif dengan lahan gembala sebagai daya dukung utama. Kepemilikan lahan gembala di wilayah ini mayoritas milik pribadi. Rata-rata kepemilikan lahan gembala adalah 0,5 hektar per peternak. Ancaman penurunan populasi di wilayah ini adalah penurunan luasan lahan gembala akibat 
pola warisan tanah dari peternak ke anakanaknya. Hal ini ditunjukkan dengan adanya penurunan populasi ternak secara drastis dari jumlah 5130 ekor pada tahun 2013 menjadi 4910 ekor pada tahun 2018 (Arifin, 2018).

Eksistensi populasi sapi Pasundan yang menyebar di wilayah Tasikmalaya berada di kecamatan Sukaraja, Cibalong, Karangnunggal, Cikatomas dan Cipatujah. Penurunan populasi terjadi di Cipatujah akibat kerusakan lahan gembala. Lahan gembala di wilayah ini menggunakan tanah negara, artinya peternak tidak memiliki lahan gembala dan menggantungkan daya dukung utamanya pada sumber lain. Penurunan populasi di wilayah Tasikmalaya sangat drastis, dari 6810 ekor pada tahun 2013 menjadi hanya 685 ekor pada tahun 2018 (Arifin, 2018). Populasi sapi Pasundan bertahan di kecamatan Sukaraja, ternak di wilayah ini dipelihara secara semi intensif dan intensif. Daya dukung wilayah untuk kebutuhan pakan diperoleh dari perkebunan milik masyarakat dan hasil ikutan pertanian.

Basis populasi sapi Pasundan di wilayah pesisir selatan Jawa Barat sebetulnya berada di wilayah Garut. Populasi ternak menyebar dari wilayah Cibalong, Cisompet, Pameungpeuk, Cikelet sampai Mekarmukti. Populasi sapi Pasundan di wilayah Garut sangat tinggi yakni mencapai 5340 ekor dan tidak mengalami penurunan populasi. Kondisi ini disebabkan oleh ketersediaan daya dukung wilayah untuk penggembalaan dengan mengandalkan lahan hutan dan perkebunan. Pola pemeliharaan ekstensif, biaya pemeliharaan ternak relatif murah dan efisien.

Potensi sapi Pasundan di wilayah pesisir selatan Jawa Barat cukup tinggi, hal ini dapat dilihat dari keberadaan populasi dan eksistensi peternak yang tinggi khususnya di wilayah basis populasi. Potensi sapi Pasundan menurut persepsi peternak antara lain reproduktivitas yang tinggi, tahan penyakit tropis, murah dalam pengelolaan dan ketersediaan pakan yang murah dengan kualitas jelek mampu memberikan performa produksi sesuai potensi genetiknya. Namun demikian gejala penurunan populasi dapat menyebabkan penurunan kualitas genetik. Menurut Arifin (2017) dampak penurunan populasi secara genetis akan mengakibatkan hal-hal sebagai berikut :

a) Penurunan kualitas genetik kuantitatif akibat seleksi negatif

b) Penurunan nilai effective population size akibat ketidakseimbangan rasio jantan : betina dalam pola perkawinan alami (INKA)

c) Peningkatan inbreeding pada wilayah basis populasi,

d) Degradasi kemurnian sapi Pasundan akibat sistem perkawinan yang tidak terarah,

Dampak penurunan populasi secara genetis perlu dievaluasi melalui eksplorasi kemurnian ternak dan ada tidaknya migrasi gen dari bangsa lain. Instrumen untuk mengukur kondisi genetik di wilayah basis populasi adalah menggunakan metode kraniometri. Warwick, et al., (1990) menjelaskan bahwa variabel-variabel ukuran tubuh masing-masing memiliki hubungan korelasional, demikian juga beberapa ukuran tubuh memiliki nilai heritabilitas tinggi sehingga pengaruh genetik aditif cukup berperan dalam pewarisan sifatnya. Pendekatan kraniometri ini

\begin{tabular}{|c|c|c|c|}
\hline $\begin{array}{c}\text { Ukuran } \\
\text { Kranium }\end{array}$ & Pangandaran & Tasikmalaya & Garut \\
\hline 1 & $44.80^{\mathrm{a}}$ & $43.27^{\mathrm{a}}$ & $45.92^{\mathrm{a}}$ \\
2 & $24.20^{\mathrm{b}}$ & $23.58^{\mathrm{b}}$ & $24.92^{\mathrm{b}}$ \\
3 & $15.73^{\mathrm{c}}$ & $14.67^{\mathrm{c}}$ & $16.33^{\mathrm{c}}$ \\
4 & $5.05^{\mathrm{a}}$ & $4.63^{\mathrm{d}}$ & $4.92^{\mathrm{d}}$ \\
5 & $35.58^{\mathrm{e}}$ & $35.88^{\mathrm{e}}$ & $33.91^{\mathrm{e}}$ \\
6 & $16.00^{\dagger}$ & $16.13^{\dagger}$ & $14.58^{\dagger}$ \\
8 & $15.08^{\mathrm{g}}$ & $12.85^{\mathrm{g}}$ & $11.95^{\mathrm{g}}$ \\
9 & $14.83^{\mathrm{h}}$ & $13.71^{\mathrm{h}}$ & $12.85^{\mathrm{h}}$ \\
10 & $17.25^{\mathrm{i}}$ & $16.58^{\mathrm{i}}$ & $17.70^{\mathrm{i}}$ \\
11 & $11.67^{\mathrm{\jmath}}$ & $11.80^{\mathrm{j}}$ & $11.83^{\mathrm{\jmath}}$ \\
\hline
\end{tabular}

dapat diaplikasikan dalam mengestimasi hubungan kekerabatan antar populasi sapi Pasundan. Berdasarkan hasil penelitian diperoleh data sebaran ukuran-ukuran kranium antar populasi, disajikan dalam tabel berikut:

Tabel 2. Ukuran-ukuran kraniometri sapi Pasundan antar populasi 
Keterangan : Huruf yang sama menunjukkan non signifikan $(P>0.05)$ pada $P=0.95$

Berdasarkan analisis varian menggunakan pola tersarang (nested analysis) menunjukkan bahwa ukuran kranium antar wilayah Pangandaran, Tasikmalaya dan Garut tidak memiliki perbedaan yang nyata. Hal ini dapat dijadikan asumsi awal bahwa konformasi kranium sapi Pasundan antar tiga wilayah memiliki kesamaan yang tinggi. Perbedaan antar wilayah pada tiap-tiap indikator tidak menunjukkan signifikansi, Dapat diasumsikan perbedaan yang tipis karena faktor pemeliharaan.

Kondisi ini dapat dijadikan indikator adanya kedekatan genetik antar populasi. Metode kraniometri memiliki beberapa kelebihan dalam pendugaan jarak genetik antara sapi bali dan nenek moyangnya banteng, dengan hasil yang cukup efektif, relatif kecil kesalahan dalam pengukurannya, waktu yang cepat serta biaya yang relatif murah dengan menggunakan cluster analysis (Mahdi et al., 2014).

Hasil analisis kluster menunjukkan adanya kedekatan genetik antar populasi. Hal ini dapat ditunjukkan pada tabel berikut :

Tabel 3. Matriks Jarak Genetik Sapi Pasundan antar Populasi Wilayah Pangandaran, Tasikmalaya dan Garut

\begin{tabular}{|c|c|c|c|}
\hline Sapi Pasundan & Pangandaran & Tasikmalaya & Garut \\
\hline Pangandaran & - & & \\
\hline Tasikmalaya & & - & \\
\hline Garut & & & - \\
\hline
\end{tabular}

Tabel 3 diatas menunjukkan bahwa sapi Pasundan di tiga wilayah masih memiliki hubungan kekerabatan yang dekat. Hal ini juga menggambarkan bahwa kualitas kemurnian antar wilayah masih tinggi. Penurunan populasi, khususnya di wilayah Pangandaran dan Tasikmalaya masih dapat ditoleransi dari aspek konservasi sumberdaya genetik. Namun demikian perlu diwaspadai gejala penurunan pejantan di tiga wilayah. Penurunan pejantan dapat mengancam nilai efektif populasi. Nilai efektif populasi yang rendah dapat meningkatkan tekanan inbreeding, kemudian berkontribusi langsung terhadap performa produksi.

Tabel 3. Agglomerasi Ukuran Kraniometri untuk Sapi Pasundan di wilayah Pangandaran, Tasikmalaya dan Garut

\begin{tabular}{|c|c|c|c|c|c|c|}
\hline \multirow[t]{2}{*}{ Tahap } & \multicolumn{2}{|c|}{ Kombinasi Kluster } & \multirow{2}{*}{$\begin{array}{c}\text { Nilai } \\
\text { Koefisien }\end{array}$} & \multicolumn{2}{|c|}{$\begin{array}{c}\text { Tahap Kemunculan } \\
\text { Kluster Pertama }\end{array}$} & \multirow{2}{*}{$\begin{array}{c}\text { Tahap } \\
\text { Selanjutnya }\end{array}$} \\
\hline & Kluster 1 & Kluster 2 & & Kluster 1 & Kluster 2 & \\
\hline 1 & 25 & 30 & 1.000 & 0 & 0 & 3 \\
\hline 2 & 21 & 23 & 1.513 & 0 & 0 & 8 \\
\hline 3 & 25 & 28 & 1.697 & 1 & 0 & 7 \\
\hline 4 & 15 & 17 & 1.803 & 0 & 0 & 27 \\
\hline 5 & 4 & 6 & 1.822 & 0 & 0 & 11 \\
\hline 6 & 13 & 24 & 1.871 & 0 & 0 & 12 \\
\hline 7 & 25 & 26 & 1.965 & 3 & 0 & 13 \\
\hline 8 & 20 & 21 & 1.994 & 0 & 2 & 18 \\
\hline 9 & 34 & 35 & 2.121 & 0 & 0 & 20 \\
\hline 10 & 1 & 2 & 2.179 & 0 & 0 & 15 \\
\hline 11 & 3 & 4 & 2.401 & 0 & 5 & 15 \\
\hline 12 & 13 & 16 & 2.449 & 6 & 0 & 18 \\
\hline 13 & 25 & 27 & 2.450 & 7 & 0 & 25 \\
\hline 14 & 29 & 31 & 2.550 & 0 & 0 & 28 \\
\hline 15 & 1 & 3 & 2.562 & 10 & 11 & 24 \\
\hline 16 & 10 & 12 & 2.569 & 0 & 0 & 23 \\
\hline 17 & 32 & 33 & 2.653 & 0 & 0 & 25 \\
\hline 18 & 13 & 20 & 2.666 & 12 & 8 & 22 \\
\hline 19 & 9 & 14 & 2.933 & 0 & 0 & 29 \\
\hline 20 & 34 & 36 & 2.947 & 9 & 0 & 28 \\
\hline 21 & 7 & 22 & 2.975 & 0 & 0 & 31 \\
\hline 22 & 13 & 19 & 3.068 & 18 & 0 & 30 \\
\hline 23 & 10 & 11 & 3.075 & 16 & 0 & 35 \\
\hline 24 & 1 & 5 & 3.114 & 15 & 0 & 26 \\
\hline 25 & 25 & 32 & 3.271 & 13 & 17 & 34 \\
\hline
\end{tabular}




\begin{tabular}{|l|l|l|l|l|l|l|}
26 & 1 & 8 & 3.487 & 24 & 0 & 29 \\
27 & 15 & 18 & 3.683 & 4 & 0 & 30 \\
28 & 29 & 34 & 3.694 & 14 & 20 & 32 \\
29 & 1 & 9 & 3.791 & 26 & 19 & 31 \\
30 & 13 & 15 & 4.024 & 22 & 27 & 32 \\
31 & 1 & 7 & 4.134 & 29 & 21 & 33 \\
32 & 13 & 29 & 4.590 & 30 & 28 & 33 \\
33 & 1 & 13 & 5.147 & 31 & 32 & 34 \\
34 & 1 & 25 & 6.253 & 33 & 25 & 35 \\
35 & 1 & 10 & 7.581 & 34 & 23 & 0 \\
\hline
\end{tabular}

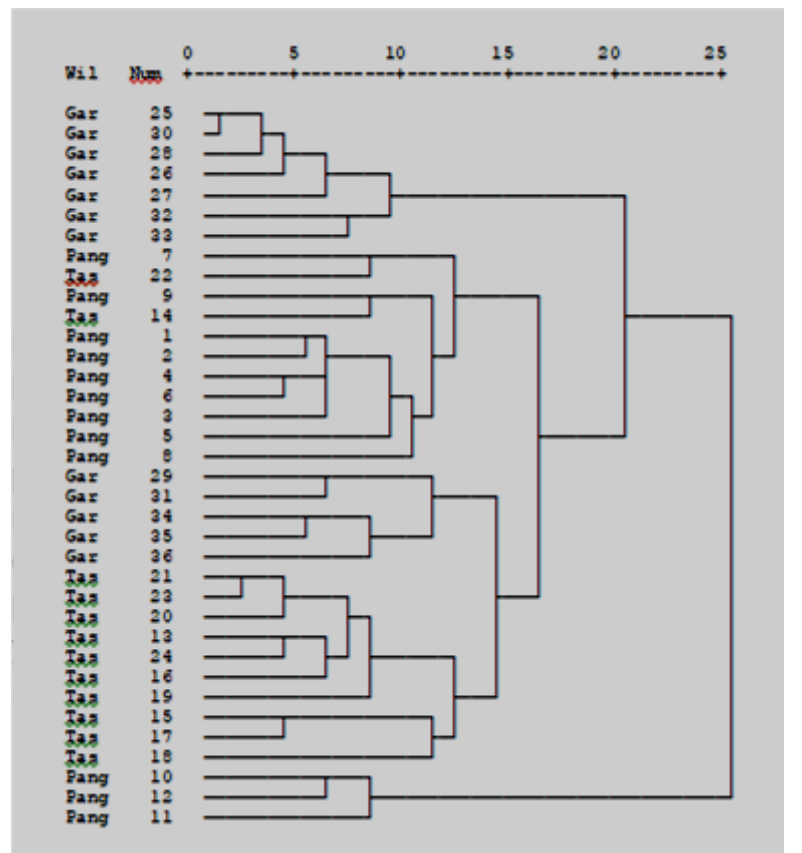

\section{KESIMPULAN}

Berdasarkan hasil penelitian ini maka dapat disimpulkan sebagai berikut :

1. Ukuran craniology Populasi Sapi Pasundan antar wilayah Pangandaran, Tasikmalaya dan Garut secara deskriptif tidak memiliki perbedaan yang nyata. Perbedaan simpangan antar ukuran craniology disebabkan oleh factor geografis yang ditunjukkan dengan perbedaan vegetasi utama dalam daya dukung wilayah.
2. Penurunan populasi antar wilayah basis populasi Sapi Pasundan di wilayah pesisir selatan Jawa Barat belum menunjukkan adanya degradasi genetik.

\section{SARAN}

Penurunan pejantan di wilayah Pangandaran dan Tasikmalaya diantisipasi gejala penurunan ukuran populasi efektif. Pemerintah perlu melakukan intervensi program, salah satunya melalui aplikasi teknologi bioreproduksi seperti super ovulasi dan inseminasi buatan menggunakan sperma pejantan Sapi Pasundan yang telah diproduksi oleh Pemerintah Provinsi Jawa Barat.

\section{PUSTAKA}

Arifin Johar. Konservasi dan Pengembangan Sumberdaya Genetik Sapi pasundan di Jawa Barat. 2017. Disertasi. Program Pascasarjana Universitas Padjadjaran. Bandung

Arifin, Daud AR, Sudirja R. 2018. Kajian Pewilayahan sumber bibit Sapi Pasundan di Jawa Barat. Riset Kerjasama Puslit Dinamika Pembangunan dan DKPP Provonsi Jawa Barat.

Arifin, J, Daud AR, Asmara IY. Pengembangan sumberdaya genetik ternak di kawasan geopark Ciletuh. [Development of genetic resources of livestock in geopark Ciletuh area]. Prosiding Seminar Nasional Teknologi dan Agribisnis Peternakan (seri IV) Tahun 2016. Universitas Jenderal Soedirman. Purwokwerto. p. 281-287. [in Bahasa Indonesia].

http://www.academia.edu/31819528/Seminar Nasional Teknologi dan Agribisnis Petern akan SERI IV Optimalisasi Teknologi dan Agribisnis Peternakan dalam Rangka $\mathrm{Pe}$ menuhan Protein Hewani Asal Ternak

http://opac.lib.ugm.ac.id/index.php?mod=book d etail\&sub=BookDetail\&act=view\&typ=htmlext \&buku id=652619\&obyek id $=1$

Mahdi, Wiyono, Suratno. Hubungan Kekerabatan Sapi Bali (Bos sondaicus 
Muller) dan Banteng (Bos bibos d'alton) Melalui Pendekatan Kraniometri. 2013. Jurnal ILMU DASAR, Vol.14 No.2, Juli 2013: 121- 128. Universitas Jember.

Menteri Pertanian RI. Surat keputusan menteri pertanian 1051/Kpts/SR.120/10/2014 tentang penetapan rumpun sapi Pasundan Jawa Barat. [Decree of the Minister of Agriculture Number. 1051/Kpts/SR.120/10/2014 on stipulation of cattle category Pasundan Jawa Barat]. Kementan RI. Jakarta; 2014. p. 103. [in Bahasa Indonesia]. http://www.pertanian.go.id/assets/upload/doc/ SURAT MENTERI 2014.pdf

Subandriyo. Pengelolaan dan Pemanfaatan Data Plasma Nutfah Ternak Kerbau. 2006. Bogor: Lokakarya Nasional Usaha Ternak Kerbau Mendukung Program Kecukupan Daging Sapi. Balai Penelitian Ternak Ciawi.

Sulasmi. Karakterisasi Sumberdaya Genetik Ternak Sapi Pasundan Berdasarkan Indeks Morfometri dan Pendekatan Kraniometri. 2016. Tesis. Program Pascasarjana IImu Ternak. IPB Bogor

Warwick EJ. Astuti JM. Hardjosubroto W. Pemuliaan ternak. [Breeding livestock]. Gadjah Mada University Press, Yogyakarta; 1990. P.19-22 in Bahasa Indonesia]. 